\title{
25. PHYTOLITHS AND MICROSCOPIC CHARCOAL FROM LEG 155: A VEGETATIONAL AND FIRE HISTORY OF THE AMAZON BASIN DURING THE LAST 75 K.Y. ${ }^{1}$
}

\author{
Dolores R. Piperno ${ }^{2}$
}

\begin{abstract}
This preliminary phytolith and charcoal study of sediments from the Amazon Fan (Sites 932 and 933) shows changes that appear to reflect widespread climatic and vegetational oscillations in Amazonia over the last 75 k.y. The Pleistocene climate was much cooler than that of the present day, as arboreal taxa now confined mainly to elevations above $1200 \mathrm{~m}$ descended into the lowlands to form forests with novel species associations. The last glacial maximum appears to have been a significantly drier time than the postglacial era, with advance of open terrain vegetation, frequent grassland fire, and reduction of the seasonal forest. Forest and grassland fires have a deep history in the Amazon Basin. Data from the Amazon Fan support many of the interpretations of the Pleistocene in Amazonia based on paleobotanical study of scattered terrestrial sites.
\end{abstract}

\section{INTRODUCTION}

The natural and human perturbations that have affected the vegetation of the Amazon Basin during the Quaternary Period are poorly understood. Brown (1982) considered that tropical forest in the Manaus area of Central Amazonia, a putative Pleistocene refugium, has very likely been stable over the last 20 k.y. Colinvaux et al. (1996), on the other hand, argued that instability of the Pleistocene climate, particularly reductions in temperature, have contributed to the high species richness of Amazonia by creating perennially disturbed environments that propelled vicariance mechanisms. Balee (1989) considered that $12 \%$ of the terra firme (dryland) forest in Amazonian Brazil might be anthropogenic, an estimate difficult to evaluate because of the paucity of archaeological and paleobotanical data from the region.

Recent studies have directly addressed the vegetational and fire history of the Amazon Basin. Pollen and charcoal records from a lake in Carajas (southeastern Amazonia, Brazil; Fig. 1) demonstrated four major episodes of vegetational change over the last 60 k.y., driven largely by alternating wet and dry periods (Absy et al., 1991). The driest period was between $\sim 22,000 \mathrm{BP}$ and $11,000 \mathrm{BP}$, when evaporation/precipitation ratios were sufficiently high to completely dry the lake bed.

Significant precipitation reduction at $\sim 40,000 \mathrm{BP}$ as well as during the last 12 k.y. of the Pleistocene has also been evidenced at the site of Katira in Rondonia province, southwestern Brazil (Fig. 1). During these times, pollen spectra show greatly increased percentages of grasses and decreases in tropical forest taxa (Van der Hammen and Absy, 1994). The natural vegetation currently is a semi-evergreen forest.

In the Napo (Ecuadorean) region of lowland western Amazonia, a paleoecological sequence recently retrieved from a swamp presents a largely uninterrupted record from greater than 40 ka until the modern era (Fig. 1; Athens, in press). Pollen and charcoal evidence indicated a dry period some time before $40,000 \mathrm{BP}$, when grass, sedge, and other savanna-indicator pollens were high and burnt grass epidermis was common. The investigator tentatively suggested that this period corresponds to the 60-k.y.-old dry time of Van der Hammen's and Absy's (1994) sites. The Napo pollen also indicated that a very cool

${ }^{1}$ Flood, R.D., Piper, D.J.W., Klaus, A., and Peterson, L.C. (Eds.), 1997. Proc. ODP, Sci. Results, 155: College Station, TX (Ocean Drilling Program).

${ }^{2}$ Smithsonian Tropical Research Institute, Box 2072, Balboa, Republic of Panama (mail only: Unit 0948 APO AA 34002-0948). STRI.Tivoli.Pipernod@ic.si.edu and moist period occurred after the drier time, and ended shortly before $40 \mathrm{ka}$ (Athens, in press).

That substantial Pleistocene cooling was a significant forcer of vegetational change throughout lowland Amazonia has been recently demonstrated by Colinvaux's team (Colinvaux et al., 1996). Pollen records from lakes in the interior of the Brazilian Amazon showed that before $\sim 11 \mathrm{ka}$, "lowland" tropical moist forest associations comprised many trees (e.g., Podocarpus, Ilex, and Hedyosmum) now largely restricted to mountain forests at elevations above $1100 \mathrm{~m}$. The inference is strong that cooling on the order of $5^{\circ} \mathrm{C}$ must have occurred to bring these taxa down from their present elevations (see also Stute et al., 1995). Finally, the recovery and dating of charcoal and phytoliths from soils underneath present-day forest (Sanford et al., 1985; Saldarriaga and West, 1986; Piperno and Becker, 1996) demonstrated that dynamic climates and fires also shaped Amazonia during the Holocene.

Although the past vegetation of the Amazon Basin is still poorly understood, the few studies undertaken strongly suggest that the Amazonian ecosystem has been far from stable. Deriving a fairly complete environmental history of the vast and diverse Amazonian ecosystem (summarized by Haberle, this volume) will rest on the discovery of many more lakes and swamps, which offer the best opportunity for detailed paleoecological study.

However, the lowland tropical forest contains few such sites suitable for retrieving paleobotanical records. Also, such factors as the sheer size of the Amazon Basin, covering an area of continental proportions, and difficulties of locating sites in remote, forested terrain present significant problems for environmental reconstruction. Records of this crucial environment from terrestrial aquatic sources may always be sparse, particularly those that extend to glacial-age time.

This report addresses the vegetational and fire history of the Amazon Basin through phytolith and charcoal analysis of sediments from Leg 155, a series of deep cores in the Amazon Fan collected by the Ocean Drilling Program (ODP; Fig. 1). Located over 700 km seaward from the Amazon River mouth where water depth exceeds 2000 $\mathrm{m}$, geological study shows that the fan received substantial discharge from the river during times of glacial low sea level (Flood et al., 1995). It has been inactive during the Holocene, when high sea level prevented sediment from crossing the continental shelf.

As all of the watersheds of the Amazon Basin should inject a phytolith and charcoal signal into the sediments, a perspective on paleoenvironments that cannot be retrieved from isolated land records is potentially obtainable. Studies of deep-sea sediments off the coasts of 
Figure 1. Map of the Amazon river catchment area (heavy line) and the drilling sites (932 and 933) on the Amazon Fan. Paleoecological sites mentioned in the text are numbered as follows: (1) Carajas, Brazil (Absy et al., 1991); (2) Katira, Brazil (Van der Hammen and Absy, 1994); (3) Napo region, Ecuador (Athens, in press); (4) Monte Oscuro, Panama (Piperno, unpubl. data).

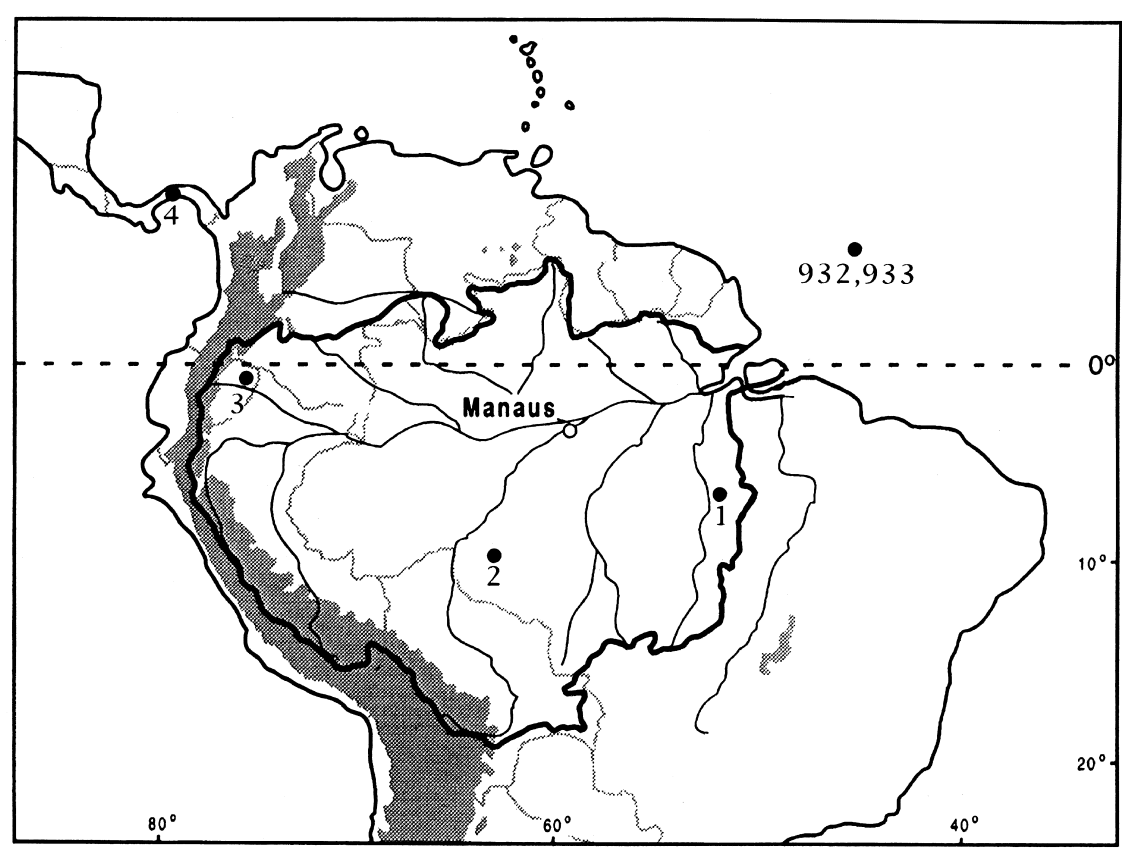

Africa and Australia have indicated that phytoliths are well preserved in such contexts, and that broad records of vegetational change may be obtained (Parmenter and Folger, 1974; Locker and Martini, 1986).

\section{METHODS}

Ten samples were analyzed from Sites 932 and 933 from the Amazon Fan (Table 1). These sites were thought to contain the most continuous records of late Pleistocene climates, particularly the crucial late glacial maximum (LGM) and subsequent termination of the Pleistocene. In addition, six samples from the Amazon Delta dating to within the last $5 \mathrm{k} . \mathrm{y}$. were studied to provide a comparison between the glacial and modern environmental conditions (Table 2). These were supplied by Dr. C. Nittrouer and Chris Sommerfield, Marine Sciences Research Center at State University of New York, Stony Brook, who are carrying out geological studies of the Amazon River Delta.

Phytoliths and microscopic charcoal fragments were extracted from sediments and quantified using standard methods of analysis (Piperno, 1988, 1993). Because they have a similar specific gravity, charcoal particles are readily separated from soil along with biogenic silica using standard procedures for phytolith work. Procedures for phytolith study often include a separation of the silt (soil particles between 5 and $50 \mu \mathrm{m}$ ) into "fine" and "coarse" fractions. Silt fractionation maximizes the recovery of phytoliths of all sizes, by concentrating smaller and larger forms into their own sections.

Phytoliths were identified by comparison with a modern reference collection of more than 2000 neotropical species, including about 500 species of trees, shrubs, and grasses from the Brazilian Amazon (Piperno, 1988, 1993; D.R. Piperno, unpubl. data). Charcoal classification was restricted to "black, completely opaque, angular fragments" taken as secure markers of fire by charcoal analysts (Clark, 1988).

When a plant is burned, it not only leaves behind charred organic debris; if the plant holds phytoliths, these are also likely to obtain a black coating indicating charring, whereas the morphology of the phytolith remains intact (Piperno, 1995). Knowledge of precisely which plants have been subjected to burning and at what frequency is thus possible through quantification of the percentages of burnt phytoliths in any taxon.
Table 1. Samples analyzed from the Amazon Fan.

\begin{tabular}{|c|c|c|}
\hline Core, section & $\begin{array}{l}\text { Depth } \\
\text { (mbsf) }\end{array}$ & $\begin{array}{l}\text { Age } \\
\text { (BP) }\end{array}$ \\
\hline $\begin{array}{c}155-933 \mathrm{~A}- \\
1 \mathrm{H}-1 \\
1 \mathrm{H}-\mathrm{CC} \\
2 \mathrm{H}-\mathrm{CC} \\
3 \mathrm{H}-\mathrm{CC} \\
4 \mathrm{H}-\mathrm{CC} \\
5 \mathrm{H}-\mathrm{CC}\end{array}$ & $\begin{array}{c}1.23-1.28 \\
5.5 \\
15 \\
24.5 \\
34 \\
43.5\end{array}$ & $\begin{array}{c}12,000-11,000 \\
? 17,000 \\
? 25,000 \\
26,000 \\
27,000 \\
28,000\end{array}$ \\
\hline $\begin{array}{c}155-932 \mathrm{~A}- \\
6 \mathrm{H}-\mathrm{CC} \\
7 \mathrm{H}-\mathrm{CC} \\
8 \mathrm{H}-\mathrm{CC} \\
9 \mathrm{H}-\mathrm{CC}\end{array}$ & $\begin{array}{l}53 \\
62.5 \\
72 \\
81.5\end{array}$ & $\begin{array}{l}69,000 \\
71,000 \\
73,000 \\
75,000\end{array}$ \\
\hline
\end{tabular}

In the records, a differentiation is made between $\mathrm{C} 3$ and $\mathrm{C} 4$ grasses based on an analysis of over 400 species of neotropical grasses, many of which grow in Amazonia today (Piperno and Pearsall, in press). Morphological differences are often apparent among the silica bodies from these two photosynthetic groups. The Chloridoid (all C4) and Panicoid (almost all C4) subfamilies of grasses contribute phytoliths that are commonly distinguishable from the Pooideae and Bambusoideae (all C3). Bamboo phytoliths are often readily identifiable at the genus as well as the subfamily level.

The distinction between $\mathrm{C} 3$ and $\mathrm{C} 4$ grasses is important. The latter, comprising many of the Panicoideae and all of the Chloridoideae, are adapted to open environments with high seasonality of rainfall and would have been likely to expand at the expense of $\mathrm{C} 3$ grasses and other tropical forest plants, the great majority of which are also C3 (Gentry, 1990; Prance, 1990) during drier climatic intervals (Bird et al., 1992).

\section{PHYTOLITH CONTENT AND TAXONOMIC COMPOSITION}

Phytoliths were present in large numbers in all of the samples analyzed. Phytolith concentrations ranged from 22,000 to 515,000/10 $\mathrm{cm}^{3}$ (Fig. 2A), quantities similar to and even exceeding those typically found in lake sediments (Piperno, 1993). The sediments deposited between $\sim 75,000$ and 69,000 BP during isotopic Stages 5 and 4 and 
Table 2. Samples analyzed from the Amazon Delta.

\begin{tabular}{lcll}
\hline Cruise & Location & I.D. & \multicolumn{1}{c}{ Notes } \\
\hline CI9113 & $03^{\circ} 28.7^{\prime} \mathrm{N}, 50^{\circ} 09.3^{\prime} \mathrm{W}$ & H2 & Composite mud sample from core, 240-590 cm interval \\
CI9113 & $01^{\circ} 14.9^{\prime} \mathrm{N}, 49^{\circ} 28.9^{\prime} \mathrm{W}$ & H5 & Composite mud sample, 0-30 cm interval \\
CI9113 & $01^{\circ} 15.0^{\prime} \mathrm{N}, 50^{\circ} 00.0^{\prime} \mathrm{W}$ & H6 & Sand from Araguari River, 30-60 cm interval \\
CI9113 & $03^{\circ} 46.5^{\prime} \mathrm{N}, 50^{\circ} 47.1^{\prime} \mathrm{W}$ & H3 & Relict mud sample from core, 60-100 cm interval \\
BBT240 & $03^{\circ} 50.0^{\prime} \mathrm{N}, 51^{\circ} 01.0^{\prime} \mathrm{W}$ & H4 & Mud sample from core, 55-57 cm interval \\
CI9113 & $03^{\circ} 28.11^{\prime} \mathrm{N}, 50^{\circ} 16.1^{\prime} \mathrm{W}$ & H1 & Sand lamination in muddy matrix, 680-685 cm interval \\
\hline
\end{tabular}

Note: All samples date to within the last 5000 years and are represented in the column marked "I.D."

from 28,000 to $26,000 \mathrm{BP}$, interstadial Stage 3, had the lowest phytolith concentrations. Changing abundances may relate to a number of factors, including sea level, surface currents, and the amount of water carried by the Amazon River, which influences sediment transport.

Haberle (this volume) also found lower abundance of palynomorphs during the above periods, presumably because higher sea levels impeded the transport of sediment across the shelf. This mechanism probably also largely explains low phytolith concentrations.

Phytolith morphology was well maintained, and phytoliths encountered were easily identified. A large number of taxa were consistently represented in the record. They include many modern representatives of the Amazonian forest recovered from plants and recent soils underneath present-day forest (Piperno and Becker, 1996), as well as unknown plants that should be identifiable as the reference collection is expanded (Fig. 2B).

It was decided to diagram the phytoliths in the fine silt and coarse silt independently, because in several samples phytolith content in coarse silt was very poor, including the crucial LGM and Pleistocene/ Holocene transition periods, plus most of the Holocene. Whether this is a result of real differences in the vegetation or some sorting process whereby larger, and thus heavier phytoliths were left behind as they moved downstream, is not at all clear at this time.

Coarse silt phytoliths are typically from trees of the tropical forest in such important families as the Annonaceae, Burseraceae, Euphorbiaceae, and Moraceae, as well as some of the Palmae and Marantaceae. Coarse silt phytolith concentration never approaches that of the fine silt, where such notorious overproducers of phytoliths as the Chrysobalanaceae, Palmae, and Poaceae (grasses) largely occur (Piperno, 1988, 1993).

Quantifying phytoliths in the two silt fractions separately does not bias the interpretation in any way because coarse silt contributes so little to the phytolith sum (typically $\sim 2 \%-4 \%$ ) anyway. Rather, in places like the lowland Amazon, one can arrive at a very good picture of the proportion of forest vs. open terrain on the landscape through fine-silt phytolith frequencies. For example, the Chrysobalanaceae, an important family of lowland trees in the terra firme forest of Brazil (Prance, 1990), are among the few taxa that, plant for plant, produce more phytoliths than the Poaceae. Hence, neither family is likely to be grossly overrepresented (compared to the other) in the records, and any tree cover changes on the landscape should be reflected in the fine silt fraction. Also, differential sorting should not have affected the representation of these phytoliths in the fan sediments because they have the same specific gravities and settling rates.

Concentration and separate examination of coarse silt ensures that changes in other important forest taxa on the landscape can be quantified because sums of several hundred phytoliths are easily achievable. Changes in coarse silt phytolith composition through time should mainly reflect changes in forest composition.

Also recovered in the phytolith preparations were other kinds of biogenic silica, mostly sponge spicules and diatoms. These were not present in amounts comparable to phytoliths, but the freshwater diatom Melosira granulata was regularly observed in some samples and not in others. Perhaps in future studies, this might serve as an indicator of well-watered areas.

\section{PHYTOLITH CHRONOLOGY}

The age models used here are based on techniques such as stable isotope analysis of planktonic foraminifers and geomagnetic field excursions of the fan (see Haberle, this volume, for a complete discussion). The samples analyzed cover segments of time from $\sim 75,000$ $\mathrm{BP}$ until the present day (Tables 1, 2). Gaps are present from $\sim 69,000$ to $30,000 \mathrm{BP}$ and $\sim 12,000-11,000$ to $5,000 \mathrm{BP}$. Five samples from Hole 932A span the period between 75,000 and 69,000 BP at regular intervals. Six samples from Hole 933A continuously cover the period from $\sim 28,000 \mathrm{BP}$ until the termination of the Pleistocene and include critical sediment from the LGM and the Pleistocene/Holocene boundary.

Work in progress on oxygen isotopes and ${ }^{14} \mathrm{C}$ dating of sections should soon increase the chronological resolution of the samples reported here, particularly the pre-22,000 BP interval from Hole 933A. Analysis of additional samples from Hole 932A to be chosen on the basis of these improved age/depth models will eventually provide a continuous vegetational record at 500- to 2000-yr intervals between 80 and $11 \mathrm{ka}$.

\section{THE PHYTOLITH AND CHARCOAL RECORDS}

Figure 2 shows the taxa represented in the phytolith record and changes in their frequencies over time. The record indicates trends during the last 75 k.y.

\section{5,000 to $69,000 \mathrm{BP}$}

The phytolith record is dominated by the Chrysobalanaceae, whose members must have been significant components of the forest. Grass (Poaceae) percentages range between 5\% and 13\%, not strikingly high, but significantly higher than the Pleistocene/Holocene transition sample and many subsequent Holocene samples (Fig. 2A). Most of the grasses were $\mathrm{C} 3$ types, with very high bamboo contribution, although $\mathrm{C} 4$ grass percentages were relatively high at $\sim 73 \mathrm{ka}$ when charcoal fragments were also common. Some of the $\mathrm{C} 4$ grasses were burnt (below).

Montane species are recorded in highest number during this interval (Fig. 2B). Not recorded, interestingly, are Pooideae (high elevation) grasses, many of which leave a distinctive signature (Piperno and Pearsall, in press). Because montane forest taxa are absent from the Holocene sections, their presence during this time must largely represent an invasion into the lowland forest propelled by significantly cooler temperatures. This is indicated by recent pollen studies from terrestrial sites (Colinvaux et al., 1996).

Also consistently present between 75 and $69 \mathrm{ka}$ are the largely lowland arboreal families Annonaceae, Burseraceae, Euphorbiaceae, and Moraceae (Fig. 2B). Certain lowland tree genera prominent in the Holocene samples (e.g. Unonopsis and/or Oxandra) are absent.

Charcoal concentrations are uniformly high during this interval, and burnt grass phytoliths are consistently recorded (Fig. 2A). Fires must have been ignited on a fairly regular basis. As no bamboo phy- 


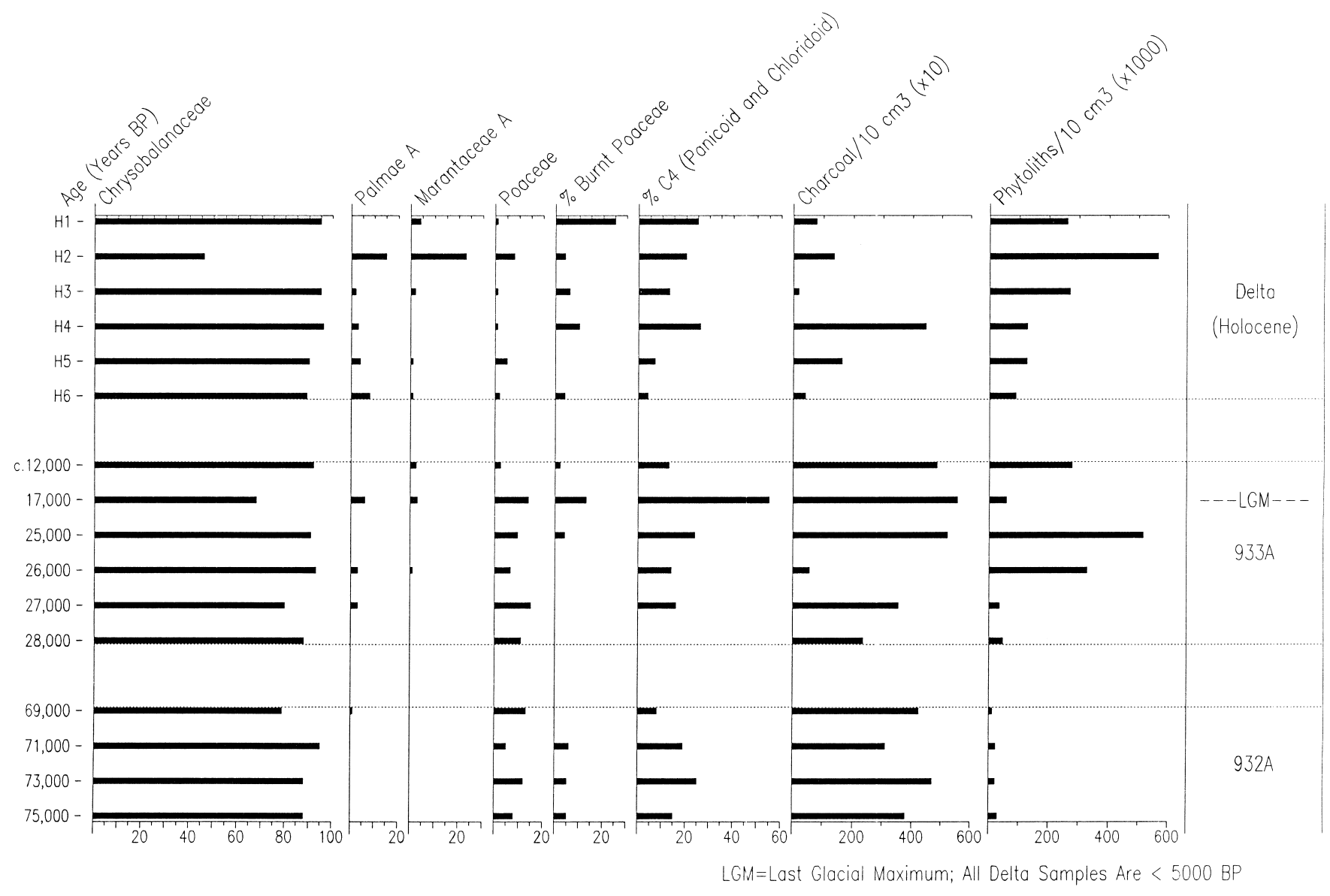

Figure 2. Phytoliths and charcoal distributions plotted against age. Sample locations are summarized in Tables 1 and 2. H1-H6 are Holocene samples from the Amazon delta. A. Phytolith and charcoal concentrations represent the total in fine and coarse silt. Percentages of burnt Poaceae and C4 plants are derived from a separate sum made by scanning at least 35-50 grass phytoliths from each level. The fine silt Chrysobalanaceae counts also may include some minimal ( $<5 \%-$ 10\%) contribution by the Dilleniaceae, Cucurbitaceae, and Moraceae (Ficus). B. The phytolith types montane forests 1 and 2, plus lowland forests 1 and 2, have been identified as high elevation or low elevation on the basis of their occurrence in modern soils from underneath various kinds of undisturbed montane and lowland forest in Panama and the central Amazon Basin (Piperno, 1993; Piperno and Becker, 1996). Other arboreal phytoliths derive largely from the Annonaceae, Flacourtiaceae, Connaraceae, and Chrysobalanaceae. The category "Other" represents unknown types.

toliths were burnt, grass fires were largely confined to $\mathrm{C} 4$ grass communities. Burnt Chrysobalanaceae phytoliths were routinely observed, indicating that fires were not restricted to areas with treeless terrain. Considering the charcoal and grass evidence, this period appears to have been a somewhat drier time than the Holocene.

\section{8,000 to $\sim 12,000-11,000$ BP}

The Chrysobalanaceae continue to dominate most of the samples, but their percentages during the LGM decreased significantly. Concurrently, grass percentage increased, and the highest percentages of both $\mathrm{C} 4$ grasses (mostly Panicoid) and burnt grasses (75\% of them C4) were recorded. Bamboo contribution was minimal here. Charcoal concentrations were also at their highest during the LGM, and burnt Chrysobalanaceae phytoliths were routinely observed. This is also the only time when burnt palm and Cyperaceae (sedge) phytoliths were observed. Palm percentages reach their highest Pleistocene frequencies during the LGM.

The Pleistocene/Holocene transition sample $(\sim 12,000-11,000$ BP) shows a large increase in Chrysobalanaceae phytoliths and decrease of grasses, C4 grasses, and burnt grasses. Tropical forest appears to have covered the landscape to a greater degree at this time and before, than during the LGM.

The LGM appears to have been the time of maximal drying, with consequent reduction of forest and expansion of open terrain with significant grass and palm cover somewhere in the basin. The steep drop in phytolith concentration during the LGM at a time of very low sea level when sediment should easily cross the shelf might indicate that rivers carried little water during this time. It is perhaps significant that although the particular species of palms cannot be identified, morphologies are consistent with those of more xeric palms that occupy drier tropical habitats.

Few phytoliths were recovered from the LGM coarse silt, although sponge spicules were fairly common. Whether this is also a result of climate change or some other unrelated process cannot be determined at this time. The next set of samples from Site 932A should, hopefully, provide more information about the response of other taxa in the lowland forest during the LGM.

A sample dated to $\sim 28,000 \mathrm{BP}$ showed significant, yet reduced, percentages of montane species, whereas at $\sim 27,000 \mathrm{BP}$, montane taxa were absent. This suggests that climate during this time was somewhat cooler than present, but not as cold as other parts of the Pleistocene, a finding also reflected in the pollen profiles from Leg 155 (Haberle, this volume), terrestrial records (Bush et al., 1990), and marine isotopic records (below). Absence of burnt grass phytoliths, plus low frequencies of charcoal particles and $\mathrm{C} 4$ grasses between 28,000 and $26,000 \mathrm{BP}$, indicate that this period was also relatively moist.

Lowland forest taxa (e.g., Burseraceae, Euphorbiaceae, Annonaceae) are represented between 28,000 and 27,000 BP, but decrease 


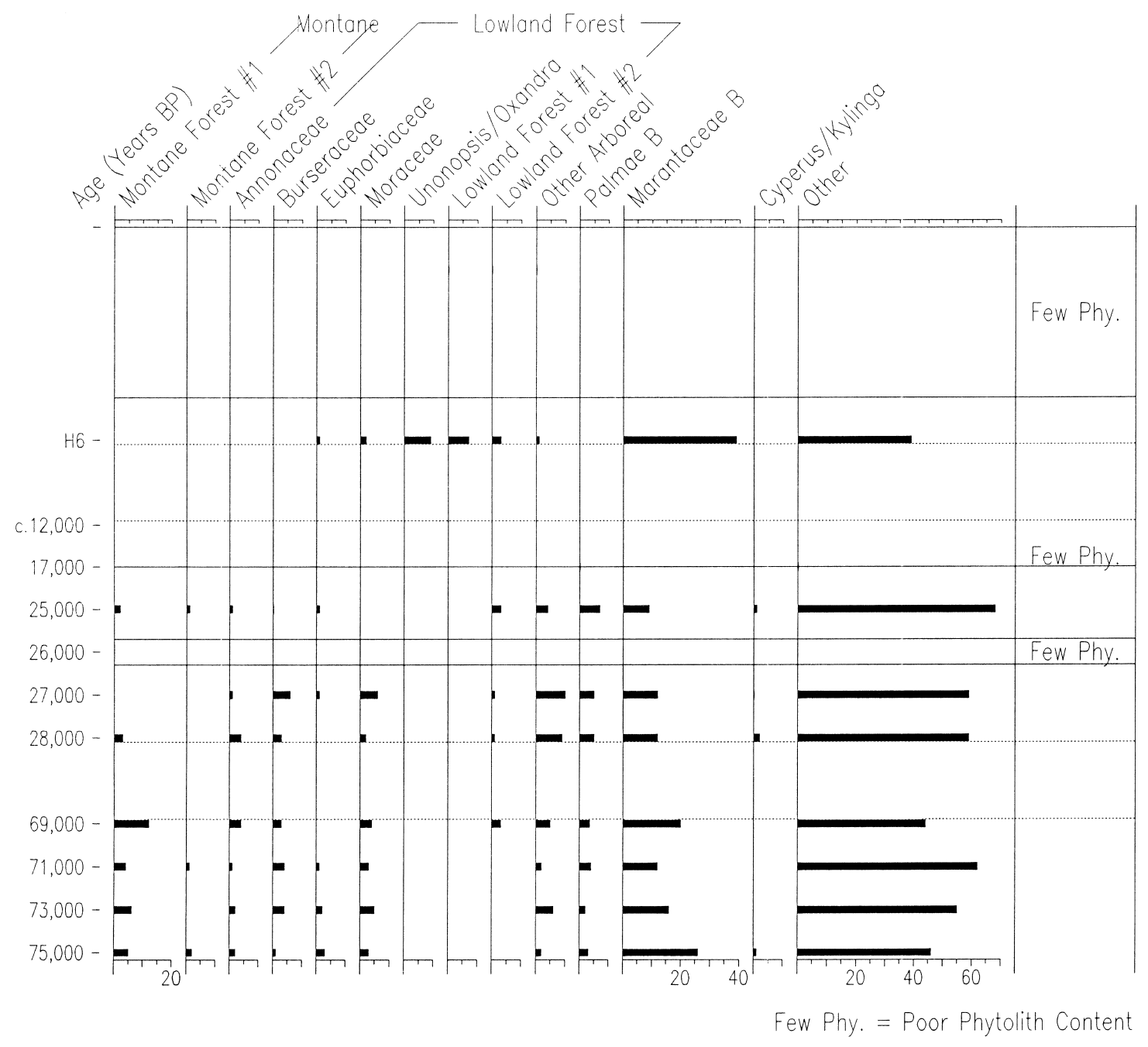

Figure 2 (continued).

along with other arboreal taxa at $\sim 25,000 \mathrm{BP}$, when frequencies of burnt grasses, $\mathrm{C} 4$ grasses, and charcoal particles begin to rise. This time may represent the onset of the drying that culminated during the LGM, a finding consistent with terrestrial pollen records (e.g., Van der Hammen and Absy, 1994).

\section{The Holocene}

All of the Holocene samples yielded a very high phytolith content in the fine silt, whereas just one sample possessed sufficient coarse silt phytolith content for interpretation. Montane species are absent, whereas several lowland forest taxa that were not recorded during the Pleistocene are present during the last 5 k.y. (e.g., Unonopsis and/or Oxandra [Annonaceae], Lowland Forest \#1). They apparently were reduced in number on the landscape by the cooler glacial conditions. Interestingly, these taxa were also absent from Pleistocene vegetational records from Panama (Piperno et al., 1991). They increased greatly in frequency at the beginning of the Holocene, further indicating their limited tolerance for the glacial climate.

The Marantaceae were much more common during the Holocene, perhaps reflecting the overall wetter climate and forests (Gentry, 1990), and/or the demise of an incised river that now annually floods its banks and creates vast wetlands in which this family can flourish. Percentages of grasses and C4 grasses, plus charcoal concentrations, were never as high in the Holocene, a time of intensive human vege- tational interference in some parts of the basin, as during the LGM. This finding further reflects the impact of the climatic change that accompanied the final $10 \mathrm{k} . \mathrm{y}$. of the last glacial period.

The Chrysobalanaceae were reduced in frequency in sample $\mathrm{H} 2$. This may purely be a function of greatly increased Marantaceae values, although a maize phytolith was detected and high percentages of palm phytoliths may also be a result of human interference (Balee, 1989). The high percentage of burnt grasses in sample $\mathrm{H} 1$ may also speak to human interference, most likely slash and burn cultivation.

The number and chronology of these samples are presently too coarse to attempt to follow the environmental perturbations caused by human or natural processes during the Holocene. However, they clearly demonstrate the differences that characterized the modern and Pleistocene environments.

\section{DISCUSSION}

How does the information from Leg 155 compare with or add to information available from terrestrial records? Significant frequency of montane forest taxa during the Pleistocene strongly points to the invasion of lowland forest by mountain trees in response to climatic cooling, as argued by Colinvaux's team of researchers (Colinvaux et al., 1996). Using adiabatic lapse rates, this cooling has been estimated to be $\sim 5^{\circ}-7^{\circ} \mathrm{C}$ (Colinvaux et al., 1996). 
Some elements of the present-day lowland forest apparently existed in the cooler glacial forests (see Colinvaux et al., 1996; Haberle, this volume), possibly in populations that were not very much reduced, although more information is needed from terrestrial deposits to properly study this important point. The dominance of arboreal taxa in many samples older than $\sim 12,000-11,000$ BP samples suggested that much of Amazonia remained forested during most of the last 75 k.y., albeit in a different state than what we study today.

Leg 155 phytolith and charcoal data also indicate that the LGM in the Amazon Basin may have been the driest time of the past 75 k.y. and resulted in forest reduction and expansion of vegetation of open ground, in which grasses were conspicuous. Percentages for arboreal Chysobalanaceae phytoliths clearly fall, whereas those of dry, openland $\mathrm{C} 4$ grasses increase substantially.

Reduction of the Chrysobalanaceae is particularly significant because this family can tolerate highly seasonal precipitation regimes. Decrease in number therefore must indicate some forest replacement in the basin. Overall grass percentage during the LGM is much higher than at the beginning of the Holocene and nearly twice as high as any sample representing the last $5 \mathrm{k} . \mathrm{y}$., when agriculture is known to have been widespread in the basin (e.g., Roosevelt, 1989).

The combination of the highest concentration of charcoal (against a declining phytolith concentration gradient) and high percentage of burnt grasses further indicates a significantly drier time when natural grass and other fires were occurring on a regular basis.

It needs to be remembered that cooling and drying were not incompatible physical forces of Pleistocene climates as suggested by Colinvaux (1993). They logically go together in the tropics. For example, the now documented (Emilani and Erickson, 1991; Guilderson et al., 1994) much cooler ocean surfaces would have contributed considerably less moisture to the air through evaporation, thereby reducing the amount carried to land by winds and precipitation, a scenario first suggested by Rind and Peteet (1985) to account for both the cooler and drier glacial climates that were beginning to be evidenced from a few tropical sites.

Results presented here thus support Van der Hammen and Absy's (1994) argument that seasonal forests in the Amazon receiving less than 2000-2500 $\mathrm{mm}$ of rain today were prone to reduction and replacement by more open terrain during the LGM. Their scenario leaves a large area of forest in the central and, especially, western portions of the basin, while reducing the forest in the broad, drier corridor to the east that runs northwest to southeast, crossing the Amazon River between Obidos-Santarem and the mouth of the river Xingu (Haffer, 1987), and in other more seasonal parts of Amazonia (Van der Hammen and Absy, 1994).

Although data presented here cannot positively specify where and to what extent open land replaced forest, the corridor mentioned above is one likely spot, an interpretation supported by existing paleoecological data from a lake located there (Absy et al., 1991; Fig. $1)$.

It is also important to note in this regard that sites investigated by Colinvaux et al. (1996) that were shown to persist in forest throughout glacial time are in some of the wettest regions of the Amazon today, receiving between 3 and $5 \mathrm{~m}$ of rainfall annually. They would not be expected to become open terrain even under a $50 \%$ reduction of rainfall, which most investigators agree is an improbably high estimate for the Amazon. In such areas, cooling appears to have been the principal force of vegetational change through most of the last 75 k.y.

Presently, phytolith data from Leg 155 cannot comment on two other dry periods proposed for the Brazilian Amazon at $\sim 60$ and 40 ka (Van der Hammen and Absy, 1994). Data presented here appear to indicate a drier than present period between 75,000 and 71,000 BP, showing that climates with reduced precipitation characterized intervals of the Pleistocene long before the LGM.
Leg 155 data support the terrestrial (Bush et al., 1990) and marine isotopic evidence (Shackleton, 1987) that the period from 30,000 to 26,000 BP (interstadial Stage 3) was one of rapid fluctuations in climate, with a brief period of temperatures at or near the present day.

One major view of Amazonian vegetation that cannot be reconciled with data from Leg 155 is refugial theory, which holds that much of the terra firme forest of the basin converted to grasslands or scrubby forest because of extreme aridity, whereas whole forest communities moved intact to moister areas (e.g., Prance, 1982; Whitmore and Prance, 1987). Again, cooling was a principal force in vegetational change, and the hilltops that captured orographic rainfall (the refugia) supported novel tree associations in which some lowland trees could not compete.

Also, the climate, although drier, cannot be called arid (below). Areal estimates of the amount of forested vs. open terrain from Leg 155 data are impossible to make, but it seems that such a reduction of the forest proposed by refugial theory would result in higher grass and lower arboreal frequencies than obtained in the phytolith record.

Conversely, the fact that a considerable part of the basin appeared to remain in some kind of forest throughout glacial time, and that the deposits studied may have a disproportional input from river- and stream-side land, which should have always remained covered by trees regardless of the character of the non-riverine vegetation, may account for why grass percentages were not higher during the LGM upon reduction of the seasonal forest.

It follows that one hypothesis derived from refugial theory may be correct: that riverine or gallery forests provided safe havens to lowland trees that were driven from their terra firme locations by dry climate (e.g., Prance, 1987). Riparian habitats during lower sea-level stands may well have offered the proper conditions for the terra firme flora-water tables neither too high nor too low, and such locales may have been major conservatories of some lowland arboreal species (see Meave and Kellman, 1994). Unfortunately, it probably will never be possible to state how much of the Pleistocene arboreal representation in Leg 155 is derived from the riverine flora.

Replacement of seasonal tropical forest by open vegetation during the last 10 k.y. of the glacial period has also been documented in Venezuela (Bradbury et al., 1981), the Peten, Guatemala (Leyden et al., 1994), and on the Pacific slopes of Panama (D.R. Piperno, unpubl. data). The latter sequence is from a lake near the Panama Canal that is called Monte Oscuro (Fig. 1). It lies at an elevation of only $20 \mathrm{~m}$ above sea level and holds a continuous series of deposits dating from the last part of the Pleistocene to the present day.

Monte Oscuro currently receives nearly $2 \mathrm{~m}$ of annual precipitation. It is estimated that at least a $35 \%$ precipitation reduction would have been needed between 20 and 11 ka to change the vegetation from the modern deciduous forest to the grass/sedge/Curatella dominated plant growth evidenced by phytolith records (D.R. Piperno, unpubl. data). The lowland forests of the Pacific slopes of Panama receiving $2 \mathrm{~m}$ of rain and less today were also subject to considerable change during the LGM. We cannot estimate the amount of precipitation reduction in the Amazon based on data presented here. Estimates drawn on the basis of vegetational change inferred from the pollen in lake sediments range from $25 \%$ to $40 \%$ during the LGM (Van der Hammen and Absy, 1994). If the upper figure was operative, one might expect to find more grass and fewer trees in the phytolith records because a $40 \%$ reduction would have removed or seriously fragmented much of the forest from the Central Amazon terra firme region. The middle to lower end of the Van der Hammen and Absy (1994) estimate may therefore generally be more accurate.

Finally, charcoal data from Leg 155 indicate that forest and grass fires have a long history in the Amazon Basin independent of the hand of man, especially during drier climatic intervals (the author believes that no compelling evidence has been forthcoming from archaeological research indicating human presence in the Basin before 
about $11 \mathrm{ka}$ ). Charcoal records from the Napo area of Ecuador also revealed that grass fires occurred well before $40 \mathrm{ka}$ and continued over major intervals throughout the Pleistocene (Athens, in press).

This preliminary study indicates that phytolithic and charcoal studies of off-shore deposits in the neotropics may yield valuable, long-term environmental histories. It is clear that the Amazonian forest produces a productive and sensitive phytolith record (see also Piperno and Becker, 1996), and that an acceleration in the construction of the modern reference collection is in order to identify the many and highly distinctive unknown types retrieved from Leg 155 sediments. Future studies of Leg 155 allied with palynological efforts will hopefully offer a more continuous and precise environmental history of the past $80 \mathrm{k} . \mathrm{y}$.

\section{CONCLUSIONS}

Phytolith and charcoal data from Leg 155 allow the following statements concerning the Pleistocene in Amazonia. The data will need to be further assessed with additional deep-sea and terrestrial data.

1. Substantial cooling, calculated to be in the order of $5^{\circ}-7^{\circ} \mathrm{C}$ from lowland lakes, was widespread throughout the basin.

2. The Amazon Basin, like other lowland areas in the neotropics, experienced substantial drying during the LGM, leading to forest reduction and expansion of open terrain in areas with pronounced seasonality of rainfall $(<\sim 2000-2500 \mathrm{~mm}$ of annual precipitation), where forests were more sensitive to precipitation changes. The driest time in the Amazon Basin over the last 75 k.y. probably occurred between 22 and $12-11 \mathrm{ka}$, although sediments in hand do not allow the study of earlier dry times suggested from terrestrial sites.

3. Climate over the last 75 k.y. has oscillated between cool and relatively moist to very cool and dry. The Pleistocene climate was dynamic, not monolithic.

4. The basin may have held the largest, continuous block of forest in the neotropics, as it does today, and supported some, but by no means all of the same trees found in modern lowland forest, making it fertile ground for studying speciation processes that have long fascinated and bedeviled modern scientists.

\section{ACKNOWLEDGMENTS}

This work was supported by the Smithsonian Tropical Research Institute (STRI) and a grant to the STRI from the Andrew W. Mellon Foundation. Thanks to Simon Haberle for valuable discussion and constructive criticism. The manuscript benefitted from excellent technical assistance by Irene Holst and Martin Mitre.

\section{REFERENCES}

Absy, M.L., Cleef, A., Fournier, M., Martin, L., Servant, M., Siffedine, A., Ferriera da Silva, M., Soubies, S., Suguio, K., Turcq, B., and Van der Hammen, T. 1991. Mise en evidence de quatre phases d'ouverture de la forêt dense dans le sud-est de l'Amazonie au cours des 60000 dernières années. Première comparaison avec d'autres régions tropicales. C. $R$. Acad. Sci. Ser. 2, 312:673-678.

Athens, S., in press. Paleoenvironment of the Ecuadorian Oriente: preliminary results from wetland sediment cores. Fron. Inves.

Balee, W., 1989. The culture of Amazonian forests. Adv. Econ. Bot., 7:1-21.

Bird, M.I., Fyfe, W.S., Pinheiro-Dick, D., and Chivas, A.R., 1992. Caron isotope indicators of catchment vegetation in the Brazilian Amazon. Glob. Biogeochem. Cycl., 6:293-306.

Bradbury, J.P., Leyden, B., Salgado-Labouriau, M., Lewis, W.M., Jr., Schubert, C., Binford, M.W., Frey, D.G., Whitehead, D.R., and Weibezahn,
F.H., 1981. Late Quaternary environmental history of Lake Valencia, Venezuela. Science, 124:1299-1305.

Brown, K.S., Jr., 1982. Paleoecology and regional patterns of evolution in neotropical forest butterflies. In Prance, G.T. (Ed.), Biological Diversification in the Tropics: New York (Columbia Univ. Press), 255-308.

Bush, M.B., Colinvaux, P.A., Wiemann, M.C., Piperno, D.R., and Liu, K.B., 1990. Late Pleistocene temperature depression and vegetation change in Ecuadorian Amazonia. Quat. Res., 34:330-345.

Clark, J.S., 1988. Particle motion and the theory of charcoal analysis: source area, transport, deposition, and sampling. Quat. Res., 30:67-80.

Colinvaux, P.A., 1993. Pleistocene biogeography and diversity in tropical forests of South America. In Goldblatt, P. (Ed.), Biological Relationships between Africa and South America: New Haven (Yale Univ. Press), 473499.

Colinvaux, P.A., Liu, K.B., De Oliveira, P., Bush, M.B., Miller, M.C., and Kannan, M.S., 1996. Temperature depression in the lowland tropics in Glacial times. Clim. Change, 32:19-33.

Emiliani, C., and Erickson, D.B., 1991. The glacial/interglacial temperature range of the surface water of the oceans at low latitudes. In Taylor, H.P., Jr., O'Neil, R., and Kaplan, I.R. (Eds.), Stable Isotope Geochemistry: A Tribute to Samuel Epstein. Geochem. Soc. Spec. Publ., 3:223-228.

Flood, R.D., Piper, D.J.W., and Shipboard Scientific Party, 1995. Introduction. In Flood, R.D., Piper, D.J.W., Klaus, A., et al., Proc. ODP, Init. Repts., 155: College Station, TX (Ocean Drilling Program), 5-16.

Gentry, A.H., 1990. Floristic similarities and differences between southern central America and upper and central Amazonia. In Gentry, A.H. (Ed.), Four Neotropical Rainforests: New Haven (Yale Univ. Press), 141-157.

Guilderson, T.P., Fairbanks, R.G., and Rubenston, J.L. 1994. Tropical temperature variations since 20,000 years ago: modeling interhemispheric climate change. Science, 263:663-665.

Haffer, J., 1987. Quaternary history of tropical America. In Whitaker, T.C., and Prance, G.T. (Eds.), Biogeography and Quaternary History in Tropical America: Oxford (Oxford Univ. Press), 1-18.

Leyden, B.W., Brenner, M., Hodell, D.A., and Curtis, J.H., 1994. Orbital and internal forcing of climate on the Yucatan peninsula for the past ca. $36 \mathrm{ka}$. Palaeogeogr., Palaeoclimatol., Palaeoecol., 109:193-210.

Locker, S., and Martini, E., 1986. Phytoliths from the southwest Pacific, Site 591. In Kennett, J.P., and von der Borch, C.C., et al., Init. Repts. DSDP, 90: Washington (U.S. Govt. Printing Office), 1079-1084.

Meave, J., and Kellman, M., 1994. Maintenance of rain forest diversity in riparian forests of tropical savannas: implications for species conservation during Pleistocene drought. J. Biogeo., 21:121-135.

Parmenter, C., and Folger, D.W., 1974. Eolian biogenic detritus in deep sea sediments: a possible index of equatorial ice age aridity. Science, 184:695-698.

Piperno, D.R., 1988. Phytolith Analysis: An Archaeological and Geological Perspective: San Diego (Academic Press).

1993. Phytolith and charcoal records from deep lake cores in the American tropics. In Pearsall, D.M., and Piperno, D.R. (Eds.), Current Research in Phytolith Analysis: Applications in Archaeology and Paleoecology: Philadelphia (MASCA, University Museum of Archaeology and Anthropology), 58-71.

1995. Plant microfossils and their application in the New World tropics. In Stahl, P.W. (Ed.), Archaeology in the Lowland American Tropics: Current Analytical Methods and Recent Applications: Cambridge (Cambridge Univ. Press), 130-153.

Piperno, D.R., and Becker, P., 1996. A vegetational history of a site in the central Amazon Basin derived from phytolith and charcoal records from natural soils. Quat. Res., 45:202-209.

Piperno, D.R., and Pearsall, D.M., in press. The silica bodies of tropical American grasses: morphology, taxonomy, and implications for fossil phytolith identification. Smithson. Contrib. Bot.

Piperno, D.R., Bush, M.B., and Colinvaux, P.A., 1991. Paleoecological perspectives on human adaptation in central Panama. I. The Pleistocene. Geoarch., 6:201-226.

Prance, G.T., 1982. Biological Diversification in the Tropics: New York (Columbia Univ. Press).

, 1987. Vegetation. In Whitmore, T.C., and Prance, G.T. (Eds.), Biogeography and Quaternary History in Tropical America: Oxford (Oxford Univ. Press), 28-45.

1990. The floristic composition of the forests of the Central Amazon Basin. In Gentry, A.H., (Ed.), Four Neotropical Rain Forests: New Haven (Yale Univ. Press), 141-157. 
Rind, D., and Peteet, D., 1985. Terrestrial conditions at the last glacial maximum and CLIMAP sea-surface temperature estimates: are they consistent? Quat. Res., 24:1-22.

Roosevelt, A., 1989. Resource management in Amazonia before the Conquest: beyond ethnographic projection. Adv. Econ. Bot., 7:30-62.

Saldarriaga, J.G., and West, D.C., 1986. Holocene fires in the northern Amazon Basin. Quat. Res., 26:358-366.

Sanford, R.L., Saldarriaga, J., Clark, K.E., Uhl, C., and Herrera, R., 1985. Amazon rain-forest fires. Science, 227:53-55.

Shackleton, N.J., 1987. Oxygen isotopes, ice volume, and sea level. Quat. Sci. Rev., 6:183-190.

Stute, M., Forster, M., Fischkorn, H., Serejo, A., Clark, J.F., Schlosser, P., Broecker, W.S., and Bonani, G., 1995. Cooling of Tropical Brazil $\left(5^{\circ} \mathrm{C}\right)$ during the Last Glacial Maximum. Science, 269:379-383.
Van der Hammen, T., and Absy, M.L., 1994. Amazonia during the last glacial. Palaeogeogr., Palaeoclimatol., Palaeoecol., 109:247-261.

Whitmore, T.C., and Prance, G.T. (Eds.), 1987. Biogeography and Quaternary History in Tropical America: Oxford (Oxford Science Publ.).

Date of initial receipt: 21 November 1995

Date of acceptance: 19 March 1996

Ms 155SR-250 